\title{
Delisting threat looms large on biotech front
}

In 2004, more biotech companies were removed from major US and European stock exchanges than in any of the past five years. A total of 11 biotech companies had been delisted as of mid-December 2004, up from only 7 in 2003, according to data from business intelligence provider BioCentury (see Fig. 1). Although poor market performance is partly responsible for this trend, those in the doldrums are often companies that do not have products advanced enough to sustain investor's interest over long periods of time.

The trend for biotech stocks runs counter to overall figures for delisting. On the New York-based Nasdaq, where many biotech and technology companies are listed, the overall number of companies removed has declined steadily since 2001. For first three quarters last year, there were only 52 stock delistings. If the final quarter results in a similar number of removals, then only about 70 companies in total will be delisted in 2004. That's down significantly from 193 the previous year.

Rules differ for various exchanges, but on the Nasdaq a company will receive a delisting warning after its stock falls below $\$ 1.00$ for 30 days. If the shares consistently remain below that price for 180 days, the stock will be removed from trading. Other factors, such as trading volume and market capitalization, are also taken into consideration during the delisting process.

This year's poor stock market performance for biotech companies with a small market capitalization as a whole may be one reason why so many are falling off major exchanges. At the end of November, the Burrill Small-Cap Biotech Index published by the eponymous investment company was down almost $6 \%$ for the year making it the worst performing index of any measured by the investment bank for that period. By contrast, Burrill's Large-Cap Biotech Index was up more than $3 \%$. In 2003, when fewer biotech compa-

\section{Box 1 Delisting affects strong biotech hubs too}

Among the companies taken off major exchanges this year, a few are well-known biotechs from California, a region considered until now as one of the most dynamic biotech hubs in the world.

VaxGen, an infectious disease vaccine company in Brisbane, California, was delisted in August after failing to file financial statements with the Securities and Exchange Commission for the first two quarters of the year. The company relies heavily on government contracts and needed to apply a revised revenue recognition policy to address them. VaxGen was founded in 1995 and went public in 1999; it raised $\$ 40$ million with its public offering and an additional $\$ 40$ million in a recent stock sale this November to private investors - enough to fund the company for several more years. VaxGen is in the process of restating revenues back through 2001 and had planned to file those restatements and apply to be reinstated to the Nasdaq in October. But as of mid-December, the company had yet to do so. VaxGen's stock is at the time of writing up to about $\$ 17$ from a recent low of around $\$ 7$ when it was delisted.

Another high-profile company, genomics research firm Sequenom, of San Diego, has been on the verge of delisting from the Nasdaq. Its stock was below $\$ 1$ for all but one day out of 30 in both September and October, but the company has not received a warning letter from the exchange. Sequenom, founded in 1994 , raised more than $\$ 250$ million in venture capital and almost $\$ 137$ million in an initial public offering in early 2000.

Among last year's delisting tales, likely more typical of many biotech companies, is anti-aging skin care and anti-impotence company Senetek of Napa. It was delisted in November and its stock price had fallen to $\$ 0.25$ as of mid-December. In 2003 , the company had revenue of more than $\$ 8$ million, down $13 \%$ from the previous year, and lost $\$ 5$ million for the year. As of November, Senetek reported only about $\$ 4$ million in cash, which given its losses last year, seems scarcely enough to keep it afloat for another year.

nies were delisted, small cap stocks were as a whole the best performers for that yearup $86 \%$.

Another difficult year for small biotechs was 2002, on the heels of the market disillusionment with genomics in 2001, when 10 of them were taken off major stock markets. In addition, only 3 companies were delisted in 2000, a time that yielded considerable investment in biotech. But the companies, that benefited from the 2000 frenzy, have not delivered yet. Indeed, roughly three-quarters of the companies that listed during the 1999/2000 biotech bubble are still not making money and therefore remain unattractive for investors, according to Tom Jacobs, cofounder of the online stock service Complete Growth Investor in Santa Fe, New Mexico.

Once delisted, a company then trades stock off the boards-and its shares are available on what is referred to as 'over the counter', also known as the 'pink sheet' or 'the bulletin board'-but its exposure to institutional investors and its ability to raise further funds are severely curtailed. A company may also remove itself from trading, which often happens in anticipation of involuntary delisting.

Alternatively, a company can do a reverse share split. For example, by exchanging ten shares for one and multiplying the stock price by ten, the company usually satisfies requirements to remain listed. "If you do a reverse split, it may buy you time, but the stock price is not going to rescue your business," comments Jacobs. In order words, those companies still need to show investors the value of their technology in the form of real products. "The biotech drug companies forced to delist have not been able to convince investors that their company is worth waiting 10 to 15 years for some chance of a return," concludes Jacobs.

Stacy Lawrence, San Francisco 